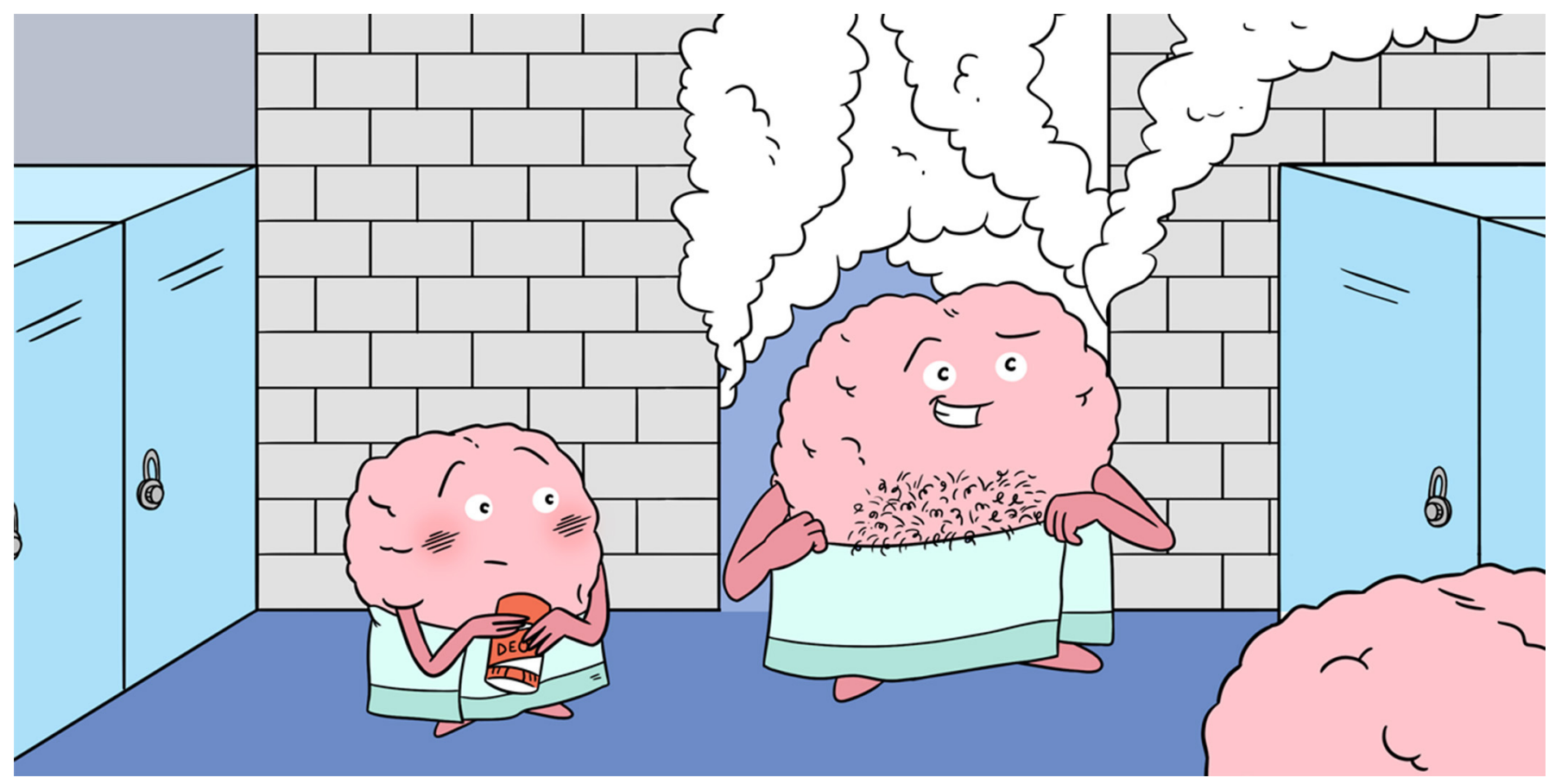

\title{
YOUR BRAIN ON PUBERTY
}

\section{Marjolein E. A. Barendse ", Theresa W. Cheng and Jennifer H. Pfeifer}

Developmental Social Neuroscience Lab, Department of Psychology, University of Oregon, Eugene, OR, United States

YOUNG REVIEWER:

A BENJAMIN

AGE: 11
Puberty is a normal part of development, but it is also different for everyone. For some teenagers, puberty comes earlier than for others, and for some it goes faster than for others. Because of this, kids of the same age can look very different from each other-their bodies are growing at different rates. However, researchers have discovered that puberty not only changes your body, but also your brain. This is because puberty involves changes in hormones that also attach to your brain cells and change how the brain learns and grows. These changes are useful because they help shape the brain for new forms of learning. They might also lead to some "bumps in the road"-for example, you might take some risks that do not quite work out. In this article we explain what puberty does to the brain, and why these brain changes are important to prepare you for adulthood.

\section{WHAT IS PUBERTY AND WHAT ARE HORMONES?}

Puberty is a normal part of development that happens in the early teenage years. When you think of puberty, you might think of zits, body odor, and hair growth-among many other, sometimes awkward body 
Figure 1

A brain cell and all its parts. The box is a zoomed in view of how hormones can attach to receptors in or on the cell. In blue is myelin, a protective sheet that wraps around the axon and allows the signals to travel faster.

\section{HORMONES}

Small messengers that travel in the bloodstream to various parts of the body. Testosterone and estradiol are two hormones that are important for puberty.

\section{RECEPTOR}

A structure in or on a cell that a hormone or other messenger can attach to.

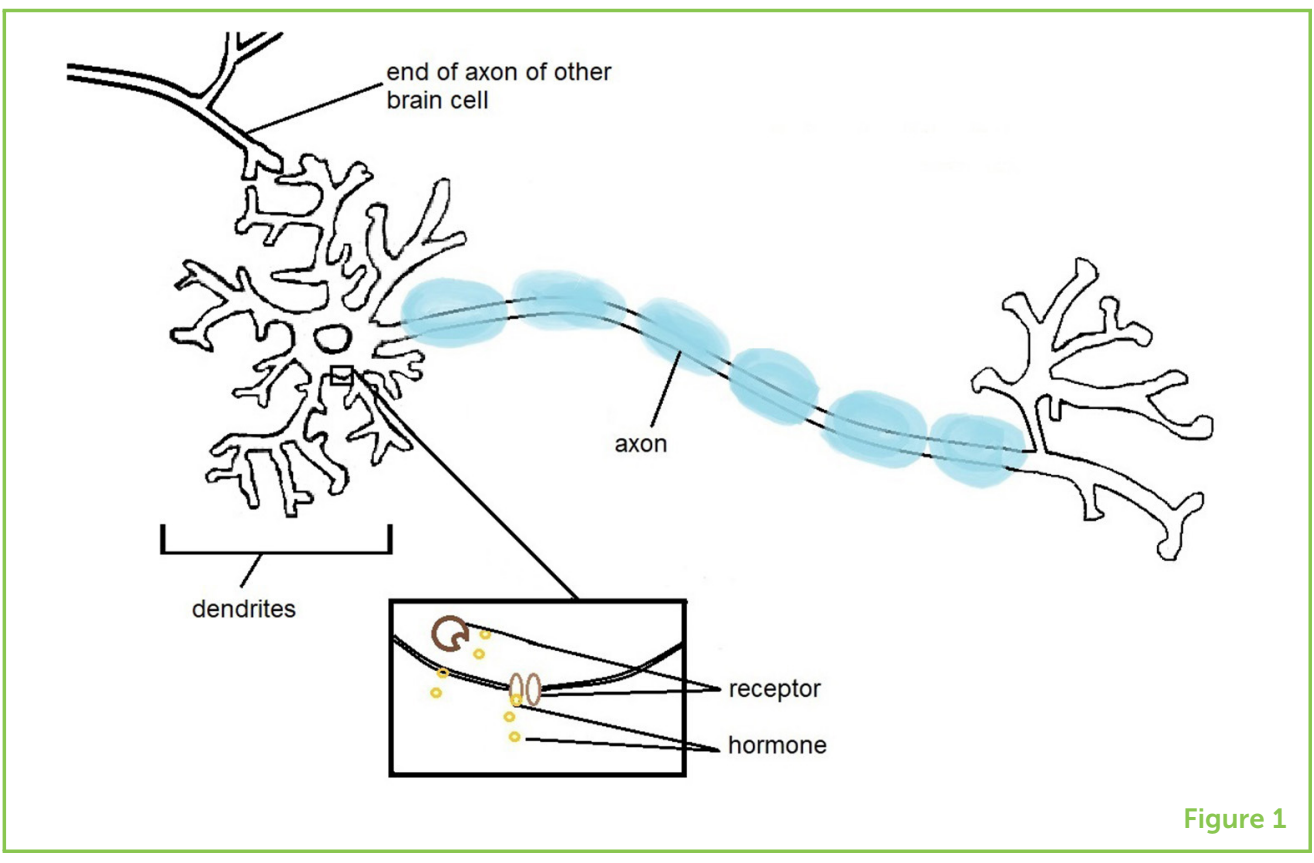

changes - but do you know what happens in your body to cause these changes? The brain signals the body to start puberty by passing along messages in the form of hormones. Hormones are small molecules made by your body that travel in your bloodstream to various parts of the body, including the brain. Hormones are important for passing messages over long distances in your body, so that different organs can communicate with each other. When a hormone reaches its destination, it attaches to what is called its receptor on or in a cell (see Figure 1). This triggers a response in the cell that can influence the cell's behavior and even its survival. How the cell responds depends on the type of cell and type of hormone.

Hormones are really important for kicking off the process of puberty. This is because puberty starts when the brain signals the body to make more of certain hormones. Figure 2 explains how this works.

Testosterone and estradiol are two important hormones that cause a lot of the body changes that people associate with puberty. Levels of testosterone increase much more in boys, while estradiol increases more in girls. Testosterone can, for example, travel to the hair cells, leading to darker and thicker hair, and hair growth on the underarms or face. Estradiol is important for breast development in girls. Both testosterone and estradiol are also important for fertility, making it possible for people to have children.

The age at which this whole process happens varies a lot from person to person. On average, girls tend to start puberty around age 10, while boys start a year later. Part of the individual differences are based on genes, but they are also partly related to experiences earlier in childhood. For example, children who have been through 


\section{Figure 2}

This figure shows how a signal from the brain leads to increases in puberty hormones. It starts in a brain region called the hypothalamus. That makes a hormone called $\mathrm{GnRH}$, which travels to the pituitary gland, a small organ at the bottom of the brain. In the pituitary gland, other hormones are made (LH and FSH) They then travel to your sex organs (these are testes in male bodies and ovaries in female bodies), which make testosterone and estradiol.

\section{DENDRITE}

The part of the brain cell that receives signals from other cells.

\section{AXON}

The part of the brain cell that sends signals to other cells.

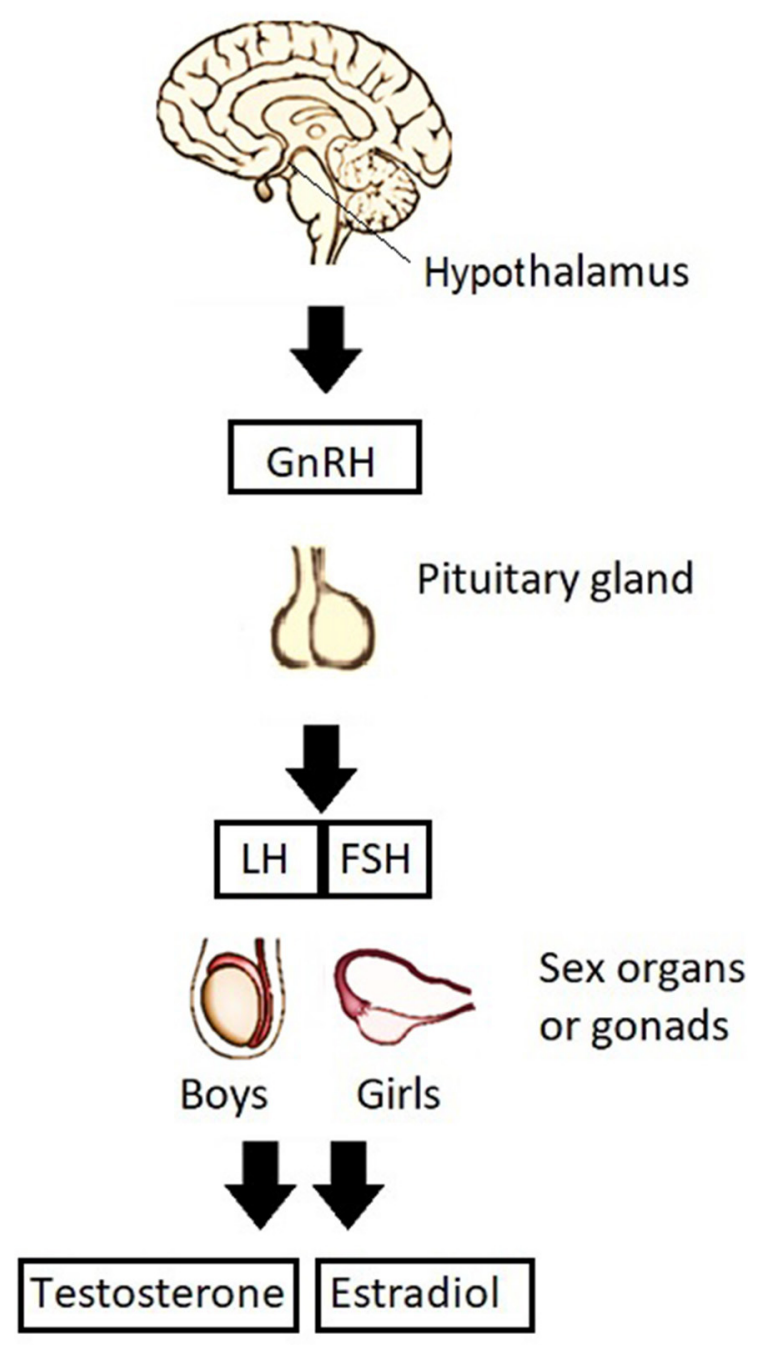

Figure 2

a lot of stressful times early in life tend to go through puberty at an earlier age.

\section{HORMONES CAN CHANGE HOW THE BRAIN IS ORGANIZED AND HOW BRAIN CELLS BEHAVE}

Hormones like testosterone and estradiol can attach to your brain cells. A brain cell looks different from cells in other parts of the body: it has a cell body, but also has parts that look like wires sticking out (see Figure 1). A brain cell often has many shorter "wires," called dendrites, for receiving signals from other cells. These cells also have one longer "wire" called an axon, which sends signals to other cells.

There are two main ways that hormones can influence your brain cells [1]. 


\section{AMYGDALA}

A small region near the bottom of the brain that is important for processing emotions like fear.
First, hormones can influence how the brain is organized, and these are changes that take some time to occur. Changes in brain organization can include changes in the number of cells, or changes in the size and shape of dendrites or axons. Testosterone, for example, influences the development of new cells in a brain region called the medial amygdala. Because boys make more testosterone during puberty, this region becomes bigger in boys than girls [2]. This was found in animal research, but studies on humans that looked at hormone levels and the size of the amygdala suggest it works the same in humans.

Second, a hormone can influence the way that brain cells become activated in response to a situation or environment. Hormones might help or prevent a cell from exchanging signals with other cells. This can also lead to long-term changes in brain cells. For example, the levels of testosterone in mice (and humans) increase during a competition or fight. One study showed that mice who win a fight develop more receptors for testosterone in brain regions that are important for reward and social behavior [3]. These new receptors might also change the behavior of the mouse in the next fight. This shows a process where experiences, like winning a fight, and hormones work together to shape brain development. This process is especially important during puberty, when the hormone levels are higher than during childhood and the brain is still developing.

There is still a lot we do not know about how hormones influence the organization and actions of brain cells in humans. We do know that these effects are different in some ways between boys and girls, and between regions of the brain. Researchers are just starting to figure out how the hormone-related changes in the brain are important for behavior and learning, so there are a lot of unanswered questions.

\section{PUBERTY MAY MAKE IT HARDER TO LEARN SOME THINGS, BUT EASIER TO LEARN OTHERS}

Children can learn certain things better than teenagers or adults can. For example, young children are particularly good at learning new languages. It becomes much harder to learn a second language after a person is 9-11 years old. This is probably because of changes in the way the brain processes speech and other language information. One study looked at the role of puberty in these changes. The researchers let children listen to speech from a fake "alien" language and studied how the brain tried to make sense of this [4]. The activity in several brain regions important for language changed as children got older. Activity in some of these language-related brain regions was also lower for children who were further along in puberty. This suggests that puberty might play a role in the brain's changing responses to language. 


\section{STRIATUM}

An area in the middle of the brain that processes rewards and feedback. It is called the striatum because the alternating types of tissue there make it look striped.
However, puberty might open a window for other types of learning. It might bring opportunities for learning about yourself and learning social and emotional skills that prepare teenagers for adulthood. The brain might change during the teenage years in ways that support such learning. For example, one important part of learning new skills is responding to feedback - that is, how your brain uses information telling you whether or not you have gotten the right answer. One study of over 200 children, teenagers, and adults looked at how the brain responds when learning from feedback. How well people learned from feedback was related to activation in different parts of the striatum, a key brain region for learning. Some parts of the striatum were more active in teenagers than in children or adults, suggesting that people might learn from feedback differently during their teenage years [5].

Another important part of learning new skills requires exploration and risks, like sharing information about yourself, trying out a new hobby that you might not be good at, or trying to talk to someone you have a crush on. Deciding to take a risk might be more likely when you think you have something to gain-like a reward. Scientists have seen that part of the striatum also activates when a person receives rewards, including food and money. One study of people ages 8-27 focused on this brain region. The researchers found that people who were further along in puberty and people who had more testosterone in their bodies showed more activation in this part of the striatum when winning a reward. This suggests that hormones may be important for making your brain more sensitive to reward during puberty [6].

These studies show that the way the brain responds to feedback and rewards changes around puberty. This may encourage teenagers to learn more about themselves and others, supporting self-discovery and personal growth. However, these brain changes might also be related to the reality that certain mental health problems and drug addictions tend to develop during the teenage years. For example, if teenagers are more sensitive to rewards, they might also be more sensitive to the rewarding feeling from taking alcohol or a drug. Also, kids who go through puberty earlier or faster than their peers can have more mental health struggles, which researchers think could be partly due to hormones having a different impact on their brains-but more research is needed to see if that is true. Most kids go through puberty without any mental health problems, and researchers are studying ways to encourage positive outcomes for even more kids.

\section{CONCLUSION}

Puberty is a time of great change, including changes that might be at times awkward, confusing, or overwhelming. Some of these changes come from the actions of hormones on cells throughout your body, including your brain. Hormones can influence your brain in the long 
term by directly changing how it is organized, or by changing how it responds to certain situations. These changes might be important for opening up new opportunities for learning that prepare teenagers for adulthood, although the same brain changes might also close windows for other types of learning that happen earlier in childhood. Schools might be able to take advantage of these brain changes in their students, for example by creating opportunities for positive forms of exploration and risk taking. Learning is more than maths and reading-making decisions that help us to better understand ourselves and others is another important kind of learning that the brain might be especially sensitive to during puberty.

\section{ACKNOWLEDGMENTS}

TC was supported by the National Center for Advancing Translational Sciences of the National Institutes of Health under award number TL1TR002371. The content was solely the responsibility of the authors and does not necessarily represent the official views of the National Institutes of Health. The authors would like to thank those who assisted in the translation of the articles in this Collection to make them more accessible to kids outside English-speaking countries, and for the Jacobs Foundation for providing the funds necessary to translate the articles. MB translated this article into Dutch.

\section{REFERENCES}

1. Schulz, K. M., Molenda-Figueira, H. A., and Sisk, C. L. 2009. Back to the future: the organizational-activational hypothesis adapted to puberty and adolescence. Horm. Behav. 55:597-604. doi: 10.1016/j.yhbeh.2009.03.010

2. Ahmed, E. I., Zehr, J. L., Schulz, K. M., Lorenz, B. H., DonCarlos, L. L., and Sisk, C. L. 2008. Pubertal hormones modulate the addition of new cells to sexually dimorphic brain regions. Nat. Neurosci. 11:995-7. doi: 10.1038/nn.2178

3. Fuxjager, M. J., Forbes-Lorman, R. M., Coss, D. J., Auger, C. J., Auger, A. P., and Marler, C. A. 2010. Winning territorial disputes selectively enhances androgen sensitivity in neural pathways related to motivation and social aggression. Proc. Natl. Acad. Sci. U. S. A. 107:12393-8. doi: 10.1073/pnas.1001394107

4. McNealy, K., Mazziotta, J. C., and Dapretto, M. 2011. Age and experience shape developmental changes in the neural basis of language-related learning. Dev. Sci. 14:1261-82. doi: 10.1111/j.1467-7687.2011.01075.x

5. Peters, S., and Crone, E. A. 2017. Increased striatal activity in adolescence benefits learning. Nat. Commun. 8:1983. doi: 10.1038/s41467-017-02174-z

6. Braams, B. R., van Duijvenvoorde, A. C. K., Peper, J. S., and Crone, E. A. 2015. Longitudinal changes in adolescent risk-taking: a comprehensive study of neural responses to rewards, pubertal development, and risk-taking behavior. $\mathrm{J}$. Neurosci. 35:7226-38. doi: 10.1523/JNEUROSCI.4764-14.2015

SUBMITTED: 30 September 2019; ACCEPTED: 26 March 2020; PUBLISHED ONLINE: 30 April 2020. 
EDITED BY: Jessica Massonnie, University College London, United Kingdom

CITATION: Barendse MEA, Cheng TW and Pfeifer JH (2020) Your Brain on Puberty. Front. Young Minds 8:53. doi: 10.3389/frym.2020.00053

CONFLICT OF INTEREST: The authors declare that the research was conducted in the absence of any commercial or financial relationships that could be construed as a potential conflict of interest.

COPYRIGHT @ 2020 Barendse, Cheng and Pfeifer. This is an open-access article distributed under the terms of the Creative Commons Attribution License (CC BY). The use, distribution or reproduction in other forums is permitted, provided the original author(s) and the copyright owner(s) are credited and that the original publication in this journal is cited, in accordance with accepted academic practice. No use, distribution or reproduction is permitted which does not comply with these terms.

\section{YOUNG REVIEWER}
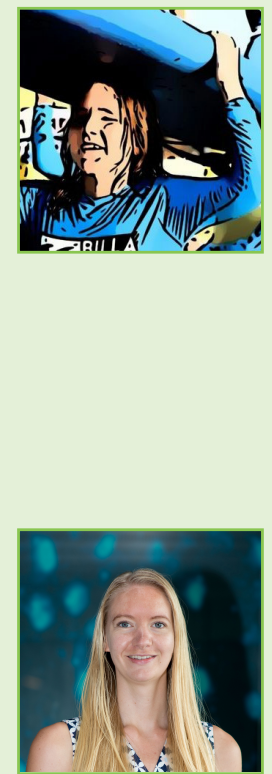

\section{BENJAMIN, AGE: 11}

My favorite subject in school is maths and english because I like to learn new information and love to be challenged. The extracurricular activities that I enjoy the most is water-polo because I love working in a team and have made many new friends. Since I saw a living brain cell firing in Oxford I have been working toward the goal of becoming a doctor. I have done this by reading many articles and listening to lectures, and I love dogs.

\section{AUTHORS}

\section{MARJOLEIN E. A. BARENDSE}

I am a post-doctoral researcher in Developmental Social Neuroscience at the University of Oregon. Before I started working in Oregon, I studied in the Netherlands and Australia. I am fascinated with how the brain works and how puberty works, and all the things that influence brain development in children and teenagers. In my free time I like to go rock climbing and travel to places I have never been before. *barendse@uoregon.edu

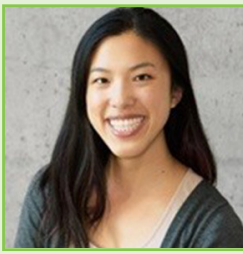

\section{THERESA W. CHENG}

I study psychology and neuroscience in the beautiful state of Oregon. In my work, I figure out how puberty, stress, and social experiences change the teenage brain. I used to be a middle and high school science teacher, and one of the best parts of my job is talking to people about science. When I am not researching, I like to cook, dance, and hike. For my eighth grade science project, I tried to show that our school cafeteria food was illegal-in other words, not nutritious enough for federal rules! 


\section{JENNIFER H. PFEIFER}

I study how the major changes adolescents experience in their brains, bodies, and social worlds relate to their well-being. I focus on times when many changes happen all at once-like when you start puberty and go to middle school, or when you finish high school and start college or work. These key transitions can be hard, but are great opportunities to set young people on positive tracks. I like playing the piano and hunting for gems at the coast. 